\title{
Sustainability as Corporate Culture of a Brand for Superior Performance
}

\author{
Suraksha Gupta* \\ Centre for Research in Marketing, Brunel Business School, Brunel University, \\ Uxbridge, UK.
}

Tel. +44 (0)1895-267924; Fax +44 (0)1895-269775; e-mail: suraksha.gupta@ brunel.ac.uk

$\&$

V. Kumar

Center for Excellence in Brand \& Customer Management,

J. Mack Robinson College of Business, Georgia State University, Atlanta, GA, USA.

Tel. (404) 413-7590; Fax: (404) 413-7585; e-mail: k@gsu.edu

* Corresponding author 


\begin{abstract}
Sustainability as practice and academic research highlight new challenges and opportunities for businesses. This paper reviews the extant literature to understand the ability of sustainable green initiatives when practiced as a corporate culture to individually create new opportunities for operations, management and marketing. According to current research, business opportunities exclusively available to different functions of a firm can drive its performance. The role of marketing in the achievement of superior performance by virtue of sustainability practices is also explained by the existing literature. Branding literature, however, fails to explain the influence of a brand on sustainability-driven opportunities available to a firm for superior performance. The objective of this study is to explore if a brand can strengthen the ability of sustainability-based green initiatives of managers to drive opportunities available to a firm for superior performance. A conceptual framework grounded in the triple bottom line theory is presented based on the assumption that brand as a stimulating factor can accelerate the conversion of opportunities available to a business into superior performance. Academic and managerial perspectives have been used to draw upon the implications of the model. Both practitioners and academic researchers will benefit from future research on this topic.
\end{abstract}

Key words: Sustainability, Green Initiatives, Product Life-cycle, Corporate Culture, Brand, Superior Performance 


\section{Introduction}

Academics and practitioners have reviewed sustainability from various perspectives (Olson et al., 2003; Fuchs \& Lorek, 2005; Sheth et al., 2011). Academics acknowledge sustainability as an approach that is adopted to meet current requirements while developing capabilities that can help focus on the future (Chabowski et al., 2011). The concept incorporates three dimensions and the academic literature explains these dimensions as economic, social and environmental (Elkington, 1998; Funk, 2003). Business researchers indicate the economic dimension of sustainability as the most desirable because it provides financial strength and avoids conditions leading to an early demise of the business due to financial reasons (Bansal \& Roth, 2000; Szekely \& Knirsch, 2005). The marketing literature discusses sustainability and highlights its role in creating opportunities and driving firm performance by taking up social initiatives understood as corporate social responsibility (Chabowski et al., 2011; Peloza \& Shang, 2011). The role of operations in making a business perform on the parameter of sustainability has been discussed as a determinant of a firm's ability to produce or deliver efficiently (Dao et al., 2011). According to business researchers, a company can perform better when its activities are performed taking account of all three dimensions of sustainability (Chabowski et al., 2011). Firms try to create a balance among these three dimensions of sustainability to secure a safer future for their business (Cronin et al., 2011). Often, the approach adopted by management for improving future performance is to create opportunities of successful delivery (Ramani \& Kumar, 2008).

From the perspective of opportunity creation, academic researchers, till now, have considered the dimensions of sustainability based on practices internal to the organisation in an individual format of either planning, production, business ethics or environmental management but not in an integrated format (Menon \& Menon, 1997; Amit \& Zott, 2001; Charter \& Clark, 2008). Adoption of green practices by a business requires managers to 
concentrate on their internal sustainable practices individually as well as in an integrated format (Drongelen et al., 2000). While integration of various actions of the organisation creates opportunities and drives superior performance, it may lead to non-green practices (Menon \& Menon, 1997). Sustainability, however, seeks to achieve this success through integration without exploiting natural resources and effectively considering the requirements of green initiatives (Baharum \& Pitt, 2009; Dao et al., 2011). Hence, it is important for managers to comprehend and reflect on future business performance of the non-green practices taken by them to perform various organisational functions (Baharum \& Pitt, 2009).

The effectiveness of sustainability-based green initiatives of marketing can be assessed from the ability of the firm to capture available opportunities by creating a differentiation for improving its future performance (Bose \& Luo, 2011). The primary role of marketing in business is to understand and fulfil the needs of customers (Kohli \& Jaworski, 1990). Today, customers recognise the roles, responsibilities and actions businesses have towards the health of the ecological environment in which businesses interact and operate (Rondinelli \& Berry, 2000).

From a sustainability perspective, managing differentiation in dynamic market conditions requires companies to continue to educate and persuade their customers about the initiatives they take for the welfare of society at large (Bridges \& Wilhelm, 2008). Brands as intangible assets of the company act as a tool to be used by managers for implementing marketing techniques that are useful for informing and educating customers (Day, 2011). Every company uses marketing techniques to communicate about its green initiatives to customers with intent to explain and highlight its contribution to the overall ecological health of society (Drumwright, 1994). Similarity in the messages received from companies makes it very hard for customers to differentiate between companies based on their green initiatives (Crittenden et al., 2011). The branding literature indicates that brand communications 
improve brand-customer association (Rust et al., 2004). Sustainability-based brand knowledge drives customers favourably towards the brand and improves the long term performance of the firm. The marketing literature on brand management reflects on the ability of a strong brand to integrate all the organisational activities and lead the company towards success (Amit \& Schoemaker, 1993; Achrol \& Kotler, 1999). Authors have underpinned the concept of a strong brand into the notion of familiarity that according to the marketing literature has the ability to drive customer beliefs about the value the brand contributes or the differentiation it creates to allow managers to overcome the consequences of low levels of trust that customers may have in the company (Kent \& Allen, 1994; Chernatony \& Drury, 2006).

Not much marketing theory is available to practitioners for explaining the ability of the brand to address the sustainability issues faced by a firm. We address this gap in research by developing sustainability-driven green initiatives as a construct that is embedded into the fundamental practices of the organisation, i.e., as a corporate culture, and the ability of this construct to provide opportunities for three prime functions of an organisation management, marketing and operations that supplement the future performance of the firm (Piercy, 2009). The core of our understanding is the role played by a brand. Hence, we assume two business-centric relationships: (1) opportunities created by green initiatives as corporate culture, which are in the form of economic development, social wellbeing and environmental protection as three dimensions of sustainability; and (2) the ability of the brand to strengthen the influence of green initiatives as marketing, management and operational opportunities on the performance of a business. We use the triple bottom line theory of Elkington (1998) as the underlying theoretical foundation of sustainability for developing the constructs and conceptualising the relationships between constructs in the form of a framework. The purpose of the framework is to enable future researchers to 
explore the influence of their brand on the outcomes of green initiatives in terms of business performance. The research propositions represented graphically by the framework support brand-oriented sustainability research. We have used product recycling through retailers to discuss green initiatives adopted by international brands and to explain the propositions and highlight managerial implications and recommendations for adoption of the framework.

\section{Research Motivation}

Today, individuals as customers understand how the activities of a firm influence the ecosystem and environment in which they live in the form of climatic changes that bring

calamities, which are very detrimental to mankind (Ellen et al., 2000). Industrial recognition and the ranking of companies, such as The Best 100 Corporate Citizens presented by Forbes, highlight commitments made and fulfilled by these companies to sustainability and improve their reputation in their stakeholder communities. Chen (2010) studied this issue empirically from the perspective of branding and green marketing to understand if there was any correlation between the green image of a brand, green satisfaction and green trust of consumers. According to the structural model presented by Chen (2010), green brand image, green trust and green satisfaction cumulatively encourage customers to pay more for green products. Today, the market for green products is increasing in size and customers anticipate that companies will comprehensively create a balance between the current environmental situation and their business interests (Chatterjee, 2009). Marketing as an organisational function can enable companies to communicate about the approach adopted and actions taken by them as green initiatives and driven by sustainability while managing their business interests (Sheth et al., 2011). Communicating to customers positively about green actions influences the behaviour of customers (Dangelico \& Pujari, 2010). A conscious effort to 
adopt a green initiative for brands offering products can be in the recycling of products at different stages of their life cycles. This practice will enable a firm to efficiently manage the waste produced as a result of products being disposed of or returned by its customers (Rogers et al., 2002).

Offering second-hand products that are at a stage of either maturity or decline in their lifecycle to a new set of customers contributes to the sustainability initiatives of the firm and provides multiple opportunities for improving the performance of the business (Pujari et al., 2003). The role of marketing in identifying customers who are ready to purchase a product at different stages of its life-cycle can successfully drive the sustainability objectives of a firm (Gunasekaran et al., 1998). In order to be able to offer products at various life-cycle stages it is important that firms try to build customer confidence in their products. Using a brand to provide confidence in the functional and emotional aspects of the product can be very useful to firms (Egan \& Guilding, 1994; Berger et al., 2002). Branded products provide an assurance to customers about the experience that they can anticipate from the use of the product (Snoj et al., 2004). When second-hand products are offered by a strong brand they have greater chances of being accepted by the customers (Kent \& Allen, 1994). Current academic research does not explain the role that a brand can play in creating opportunities such as driving customers to purchase second-hand products through green initiatives. Our motivation is to elicit the knowledge of academics and practitioners about (1) the ability of green initiatives to create opportunities for improving firm performance, and (2) the role played by a brand in enabling green initiative-based opportunities to drive firm performance.

\section{Theoretical Underpinning}

The concept of sustainability originated in the academic literature as a concern about the deteriorating environmental and climatic situations as a consequence of the economic and 
social development of society (Batie, 1989; Munasinghe, 2001; Fadeeva, 2005).

Sustainability when viewed from a business perspective has been explained in the literature as an organisational practice that encourages minimisation of the energy used and efficient use of the waste produced so that negative effects of the firm's actions on the human race can be reduced (Eltayeb et al., 2010).

\section{Brand-oriented view of sustainability}

Sustainability researchers such as Bronn \& Vironi (2001) recommend that marketers should apply the triple bottom line theory to build reputation, while Ratnayake and Liyanage (2009) indicate that management practitioners should move away from a one-dimensional financial perspective of business relationships to a holistic view of societal relationships for incorporating sustainability into the culture of the company. A brand acts as a tool that integrates a business with its social environment by creating associations between the company and its customers (Grace \& O'Cass, 2002). Brand associations contribute to the sustainability by participating in the green initiatives of the brand (Chatterjee, 2009). When a green initiative is communicated to customers as a brand communication it has a favourable impact on their behaviour (Wong et al., 1996). Brand communications help in building beliefs of customers about its green initiatives and develop their confidence in the intentions of the brand to act favourably for the long term needs of society (Pomering \& Dolnicar, 2009).

\section{Industrial Orientation}

LeBreton et al. (2004) reflected on the efficient use of ecological supportive opportunities used by firms while managing their businesses through industrial networks of small and medium enterprises. They found that the collaboration of a manufacturing firm with smaller firms in an industrial network can yield the desired economic, social and environmental 
benefits and lead to superior performance. The green initiative of recycling and managing waste of branded products at different stages of their life-cycle generates various opportunities for the firm that owns the brand. Such initiatives drive not only environmental but also the social and economic dimensions of sustainability by satisfying the needs of customers belonging to various sections of society with recycled products and bringing financial benefits for the brand, consumer and retailer. While consumers earn a loyalty incentive when they return an old product for recycling and buy a new product of the same brand, retailers collect old and used products from consumers as a part of loyalty schemes run by the brand, brands provide opportunities to the retailer to refurbish used products and offer them again to a new set of consumers who are ready to buy second-hand but efficient and branded products. In the bargain, retailers as members of industrial networks earn more profits and enable brands to capture a greater share of the market.

Economic and environmental integration of a business with its social environment is very important for a sustainable performance. The role of industrial networks in building strong brands (Roberts \& Merrilees, 2007) and the role of industrial brands in improving firm performance (Weerawardena et al., 2006) in the academic literature is well understood. However, the influence of a brand on the ability of opportunities created by sustainabilitydriven green initiatives on performance of the business is unclear. This study synthesises the existing knowledge from various different domains such as marketing, operations and management to conceptualise the role of brand in driving opportunities available to a firm through adoption of green initiatives for superior performance (Razzaque, 1998; Crittenden et al., 2011).

The primary objective of this paper is to suggest a research agenda in the form of a framework (Figure 1) that depicts the role played by brand in strengthening the influence of sustainability-based green initiatives of a firm for superior performance by creating 
opportunities. The proposed model merges sustainability and branding theories by denoting the corporate culture and consumer behaviour aspects of green brands for superior performance. The assumptions made are conceptually embedded into the theory of triple bottom line of sustainability which is based on three elements, namely people, profit and planet (Elkington, 1998; Marrewijk, 2003). The next section of this paper will discuss the relationships assumed by the researchers. A typology is presented to explain the school of thought and a framework is conceptualised to depict the relationships between the constructs.

\section{<Insert Figure 1 about here>}

\section{Research Propositions}

Marrewijk (2003) reviewed the philosophical aspect of the triple bottom line theory and linked it with a firm's initiatives driven by sustainability for making its business green. Perrini (2006) studied the diffusion effect of triple bottom line elements individually in different dimensions of sustainability and found that they embrace the adoption of green initiatives by different functions of the firm. The focus of operations on the triple bottom line drives quality, rigour and utility of the outcome of actions of a firm as its performance (Seuring \& Muller, 2008). Chabowski et al. (2011) adopted the capability- and resourcebased perspectives to understand the role of marketing in attainment of sustainability and identified the development of distinctive capabilities to respond to customers as an antecedent to the financial performance of a firm. Hart (1995) and Russo and Fouts (1997) highlighted the role of management in shaping corporate policies relating to the society in which a firm operates using resource-based theory and recommends it to be established as corporate culture for improving the internal capabilities and performance of a company. 
Elkington (1998) used the triple bottom line theory to recommend sustainability as a cultural revolution for organisations, based on seven initiatives that can be detailed as follows:

(1) markets to be driven by competition, i.e. the old market paradigm considers them to be compliant but the new paradigm of driving sustainability as a corporate culture highlights that they should be considered as competitive;

(2) to drive the corporate culture of sustainability, managers should change their consideration of corporate value from hard to soft, i.e. pay greater attention to human values;

(3) companies should become more open and transparent in their operations contrary to the traditional closed way of operation to demonstrate their thinking, priorities and commitments through activities;

(4) the technology life-cycle should be related to the efficiency of the function it performs during its life-cycle rather than considering it as a product;

(5) business partnerships should be seen as symbiotic instead of subversive and competitors should be seen as cooperating with each other through a relationship for a common cause;

(6) time in business should be considered as longer rather than wider with philosophies such as just-in-time to expand horizons and encourage creativity;

(7) corporate governance should become inclusive rather than exclusive by its design and value chain if a company wants to change the corporate culture towards adoption of sustainability practices for converting its sustainability-driven actions into green initiatives (Table 1). Embedding sustainability into the culture of an organisation leads to identification of new opportunities (Miller, 2003). 
<Insert Table 1 about here>

\section{Sustainability-driven Green Initiatives}

The concept of sustainability justifies the rational needs of a company (Crittenden et al. 2011) and proposes the adoption of environmentally-friendly sustainable practices by managers while they intelligently attend to the constraints in a way that their actions do not lead to either destruction of natural resources available to society or drive customers to over consume the company's products (Wheeler et al., 2003; Sheth et al., 2011). Researchers have termed the adoption of such sustainable practices as green initiatives (Hart, 1997). To adopt sustainability-driven green initiatives, managers try to concentrate on factors that are both internal and external to their firm (Lockwood, 2006). While it is challenging for managers to drive external factors for adoption of sustainability-friendly green practices because they are beyond their control (Williamson et al., 2006), the differences in objectives of different factors internal to the firm also act as a barrier to adoption of green initiatives and affect firm performance (Szekely and Knirsch, 2005).

Our first three propositions focus on the recommendations of Elkington (1998) that the triple bottom line agenda floats between a production unit to the board room as efficient use of resources available for the environmental dimension, green consumerism for the social dimension, and globalisation for the economic dimension from a perspective of sustainability as a corporate culture. We have tried to understand the individual effects of embedding three dimensions of sustainability into the corporate culture as a stimulant for a company adopting green initiatives.

P1a: Firms that emphasise the economic dimension of sustainability will have a higher probability of the presence of green initiatives in their corporate culture. 
P1b: Firms that emphasise the social dimension of sustainability will have a higher probability of the presence of green initiatives in their corporate culture.

P1c: Firms that emphasise the environmental dimension of sustainability will have a higher probability of the presence of green initiatives in their corporate culture.

Transforming a business completely into one that ensures that actions taken across its corporation are green, i.e., leading to economic development, social wellbeing and environmental protection, is an aim that is difficult to achieve. Green initiatives cannot be reenforced into the culture of the company unless activities assumed to be difficult by managers are made relatively simpler and considered easier. According to research on business sustainability, the construct must be seen as a broad concept that incorporates managerial concern for the economic, social and environmental dimensions of the business. Different strategies pursued by managers to achieve sustainability might be based on their business preferences. The strategies adopted clearly reflect both the ease and difficulty of implementing these three dimensions together. Incorporating green initiatives strategically into every action of the company as its corporate culture requires managers to understand and determine the strength and future implications of each individual dimension of sustainability. In order to enable managers to make such assessments, we assume:

P1d: The impact of the economic dimension of sustainability will be stronger by incorporating green initiatives into corporate culture in comparison to the social dimension which, in turn, will be greater than the environmental dimension.

\section{Green Initiatives as a Corporate Culture}

A sustainability approach requires a company to adopt green initiatives and become an ecofriendly green business (Szekely and Knirsch, 2005). Business regulations anticipate that 
companies will adopt sustainable and socially responsible practices for making profits (Minoli, 2010). The eco-friendly green activities of a business entail running a business in a way that encourages it to contribute towards the creation of an ecological balance for improving the health of the planet through its various business functions, such as marketing, management and operations (LeBreton et al., 2004). Galbrith et al. (2002) proposed a model that incorporates five elements together, namely people, strategy, structure, processes and rewards, in order to drive the culture of an organisation towards sustainability.

The people dimension of the model has been emphasised by various other authors in order for employees to have a clear understanding about the concept of sustainability (Garriga and Mele, 2004; Kemp et al., 2005). The role played by strategy has also been explained in the academic literature as organisational vision, mission, objectives, goals and values imbibed into the concept of sustainability, so that managers and employees do not have to make an extra effort to focus on adopting green initiatives while making business strategies or taking routine decisions (Gupta 2007, Breja et al., 2011). The literature on leadership explains the dimension of the organisation's structure and proposes it to be designed in such a way that an identified decision-making authority is available within the organisation to ensure that organisational processes maintain the context of sustainability (Stone, 2006; Coakes et al., 2008). Organisational processes when performed considering the three dimensions of sustainability create new opportunities and influence an organisation's performance (Lee et al., 2001).

Strategically involving sustainability in the culture of the firm through processes can be achieved by creating a workplace wherein employees feel safe to express themselves and share information and their personal ideas about the influence of firm actions on its eco friendliness (Galbrith et al., 2002). An ethos of open communication can make employees feel that they are part of a company's initiative and encourage them to contribute to the 
mission of their firm, which is to become a green business (Smith, 2010). Such open communications motivate every individual involved with the organisation to express his/her opinion and drive its green initiatives towards success (Bernaur \& Caduff (2004). Appointing sustainability campaigners within the organisation and incentivising them to execute green strategies and engage staff in generating newer green ideas can drive sustainable practices (Bridges \& Wilhelm, 2008). An open communication channel with employees can allow managers to be informed, understand and collaborate within the organisation with other employees to innovate sustainable practices at a suitable time (Wehling et al., 2009).

Russo and Fouts (1997) adopted the resource-based view of the firm to study the strength of a relationship moderated by industry growth between two prime constructs, corporate environmental performance and profitability, empirically using data collected from 243 firms over two years, and found that the green initiatives of a company become a competitive advantage and influence the performance of the firm (Melynk et al., 2003). As proposed by Marrewijk (2003), every function of the firm should be put under the scanner of sustainability so that managers can weave such practices into their business decisions and make their business a green business. The argument is based upon the notion that an organisation's functions do not yield the outcomes desired by businesses when considered from individual dimensions of sustainability and not holistically. Halme and Laurilla (2009) investigated the relationship between corporate responsibility and financial performance of large firms and found that corporate responsibility when pursued strategically by firms contributes less to the financial performance of the company - philanthropic activities in particular do not pay higher returns as anticipated by managers. As explained by Newton and Harte (1997), a green business is committed to making profits by supporting ecological requirements while providing environmentally friendly products or services to its customers. 
The corporate culture of supporting the ecological and environmental requirements of society directs managers to become conscious of the resources used, waste produced and energy consumed during the running of their business and requires them to conserve these with the help of green initiatives (Shrivastava, 1995; Newton \& Harte, 1997).

Sustainability when incorporated into the corporate culture (Fiol, 1991) enables managers to create new opportunities for businesses (Menon \& Menon, 1997). The concept indicates that managers should develop business models that not only support green initiatives (Eltayeb et al., 2010) but also use green initiatives to create further opportunities for their business. Green initiatives allow businesses to make optimum use of natural resources such as solar energy and efficiently manage the waste from their products by recycling them at various stages of life-cycle (Bridges \& Wilhelm, 2008). This research conceptualises the ability of such green initiatives that are embedded into sustainability to create opportunities, such as improving performance, increasing customer base and strengthening business relationships for different functions of an organisation, namely, management, marketing and operations, as discussed in the following sections.

\section{Marketing Opportunities}

Sustainability, when practiced as a corporate culture, develops new marketing opportunities for managers (Teece \& Pisano, 1994). Practices of sustainability enable marketers to communicate about the orientation of their firm's values and beliefs towards not only satisfying the needs of customers but also towards improving the life of its stakeholders as the company's prime objective (Menon \& Menon 1997). It enables marketers to create a differentiation by communicating the firm's green initiatives, such as using environmentally friendly material for packaging the products, or reducing carbon footprints by minimising the use of paper by avoiding hard copy mailing and instead communicating electronically 
(Shrivastava, 1995). Designing target-based campaigns leads to reduction of the waste produced as a result of promotional campaigns (Frame \& Newton, 2007). Marketing initiatives, such as creating awareness about the benefits of sustainable products or services can position the firm above competitors and enable it to enjoy a better reputation (Menon \& Menon, 1997). Such initiatives act as a stimulus for customers to buy green products and improve the long term viability of the business by helping firms to leverage on its green innovations for economic, social and environmental dividends (Boulatoff \& Boyer, 2009). Sustainability-based green initiatives of a firm when acknowledged by entities operating both internally and externally to the organisation influence the firm's reputation and become its identity over a period of time (Rodrigues \& Child, 2008).

\section{Management Opportunities}

Sustainability encourages the smart management of resources so that it brings opportunities for efficient management of costs and wastes (Geng \& Yi, 2006). The objective of sustainability in the domain of business is to let firms deal efficiently with their future risks by caring for the financial health of the company while considering the health of people and the planet (Osland, 2003). The management's approach to sustainability by improving gaps in the green activities of the firm provides various opportunities that lead to better performance (Ratnayake \& Liyanage, 2009). While the management tries to utilise its resources efficiently and manage its costs and waste through green initiatives, it encourages marketing to motivate consumers to be mindful of their consumption of the products offered by them (Sheth et al., 2011). The objective of the management in such initiatives is to make all individuals aware of the needs of the environment and motivate them to contribute to sustainability by stimulating them to use sustainable products or services (Sheth et al., 2011). Development and adoption of technologies or information systems for sustainable development by management enables identification of gaps or setbacks to the efficiency of 
the firm with the areas of improvement (Szekely \& Knirsch, 2005). Information required to drive sustainability-based green initiatives can be achieved in various ways: from a sustainability performance reporting system; consulting with different communities to understand their requirements linked to sustainability; setting up a programme that allows the exchange of second-hand products to reduce waste; identifying investments to become a socially responsible organisation; labelling products with eco-friendly messages to educate customers. Sustainability-based green initiatives provide a performance-oriented roadmap to businesses and lead to a reduction of risks and costs with opportunities such as enhanced reputation, cleaner production and environmental accounting.

\section{Operations Opportunities}

Caring for profit, people and the planet demands strategic innovative processes that improve the performance of a firm in an environmental context and bring attractive financial dividends to the firms (Kantabutra \& Avery, 2011). Some examples of drivers of change in the operations domain are good governance, capacity development, knowledge-based solutions and partnerships. Good governance based on sustainability involves natural resources utilised, optimum inventories created and minimum waste produced by operations. Such governance provides opportunities for efficiently complying with the standards prescribed by related authorities and successful fulfilment of long term requirements of the people and the planet (Szekely \& Knirsch, 2005). Involving the employees in nurturing the culture of sustainability within the organisation can bring opportunities of capacity development by encouraging them to efficiently participate in total quality management, innovative production and efficient supervision (Lee et al., 2001). Such initiatives can be noticed in companies whose operational functions work on simple solutions that reduce the functional complexities and improve profitability. These initiatives should be aligned not only to the company's own environmental requirements but also to those of its customers. 
This dual alignment encourages partnership-based relationships with clients and fulfils the basic requirement of companies to grow with a stronger reputation (Fuller \& Tian, 2006). Addressing operational requirements such as efficient infrastructure or financial support for successful operations with focus on sustainability-driven green initiatives provides new opportunities for using specialised knowledge-based expertise that improves the performance of the firm (Szekely \& Knirsch, 2005).

When green initiatives become part of the corporate culture, they provide opportunities for superior performance to different functions of the organisation. Sustainability-driven green initiatives help the management team to involve every stakeholder in adoption of green initiatives and benefit from the outcomes of adoption in terms of increased profits through reduced costs (Bansal \& Roth, 2000). Such adoption drives operations to efficiently use resources and manage waste produced as a result of the firm's business activities and allows marketers to create differentiation by improving the image of their company (Shrivastava, 1995; Bansal \& Roth, 2000; Szekely \& Knirsch, 2005).

A synthesis of the opportunities provided by green initiatives to three different firm functions improves the overall performance of a company. The following propositions address the role of green initiatives in creating opportunities for improving performance for three prime functions of an organisation, namely management, marketing and operations.

P2a: Approach to sustainability based on green initiatives as corporate culture when incorporated within the operations function of a firm creates more opportunities for improving performance.

P2b: Approach to sustainability based on green initiatives as corporate culture when incorporated within the management function of a firm creates more opportunities for improving performance.

P2c: Approach to sustainability based on green initiatives as corporate culture when incorporated within the marketing function of a firm creates more opportunities for improving performance. 
Sustainability for businesses means adopting practices that will not degrade or destroy natural resources while they try to maintain a strong financial base (Swaney, 1987). While sustainability initiatives are known to drive changes such as reduction in carbon footprint and increase in efficiency of available resources, incorporation of green initiatives in the actions of the firm at the planning stage is very important (Judge \& Douglas, 1998). This incorporation should occur in such a manner that it can be easily articulated and smoothly capitalised as opportunities by managers (Geng \& Yi, 2006). While the study conducted by Stubbs (2004) recommends that tradeoffs between the three dimensions of sustainability can create an environment that will be suitable for the application of sustainable policies and laws in an organisation, we argue that it will also bring new opportunities for improving the performance of different firm functions and it is very important that managers are able to evaluate the right trade-off required between what functions and how much. Hence, we assume that:

P2d: The ability of green initiatives adopted as corporate culture by a firm to create opportunities for improving performance will be highest for operations when ranked in comparison to management followed by marketing as organisational functions.

This section has explained the opportunities created by sustainability-driven green initiatives for marketing, management and operations which influence the performance of the firm. The next section argues that the presence of a brand strengthens the relationship between opportunities available and performance of a business.

\section{Brand-oriented green initiatives for superior performance}

Urde (1999) proposed brand orientation as a strategic resource useful for influencing customers in competitive markets. The susceptibility of a weak brand to be able to sell mainly on price point moved the product-based marketing strategies of international firms to 
brand-based marketing strategies and encouraged them to develop strong brands (Duncan \& Moriarty, 1998). A brand considered to be strong enjoys robust customer equity due to consistent differentiation by delivering meaningful value for every stakeholder (Szekley \& Knirsch, 2005). The brands that provide superior value to customers are perceived to be sustainable and strong (Srivastava et al., 1998). A strong brand requires managers to clearly articulate the brand in a manner that creates associations that are stronger than those of competitors (Kent \& Allen, 1994; Grace \& O’Cass, 2002). A strong brand association influences stakeholders while they take business-related actions, like identifying opportunities, and drives them to capitalise on those opportunities by prioritising their actions in favour of the brand (Szekley \& Knirsch, 2005). Strong brand orientation not only provides opportunities to charge a premium but also gives extra confidence to customers about the product being offered by the brand (Srivastava et al., 1998).

Favourable intent of customers towards a strong brand makes the organisation secure about its market share and allows managers to think beyond routine decisions regarding profits and become innovative and considerate in their functioning towards society (Payne et al., 2009). Socially ethical thinking drives managers to adopt the approach of sustainability in the firm's practices and encourages them to take green initiatives (Bansal \& Roth, 2000). Green initiatives adopted by a brand require managers to make optimum use of the resources available to the organisation and reduce the waste produced (Rondinelli \& Berry, 2000). A strong brand that sells through a retailer network can use its retailers as its resources and make use of their employees as brand champions. These brand champions can capitalise on their relationships with consumers to communicate and promote brand policies to incentivise customers who are ready to either provide an old product for recycling or repurchase a new product for the sake of brand loyalty (Mentzer et al., 2000; Palmatier et al., 2007). 
Such initiatives not only provide marketing opportunities for identifying customers who are ready to purchase second-hand products of the brand, but also to the management for working out a new and innovative revenue model for both the brand and the retailer and to explain operational opportunities for both retailers and the brand to understand the revenue they will generate from making old products recyclable and ready to be used by a new set of customers. Hence, our third proposition addresses the role played by a brand in strengthening the success of opportunities provided to marketing, management and operations by sustainability-driven green initiatives of a firm as improved performance.

P3a: The presence of a strong brand will improve the ability of operations to utilise opportunities for superior performance, based on the sustainability-driven corporate culture of green initiatives.

P3b: The presence of a strong brand will improve the ability of management to utilise opportunities for superior performance based on the sustainability-driven corporate culture of green initiatives.

P3c: The presence of a strong brand will improve the ability of marketing to utilise opportunities for superior performance based on the sustainability-driven corporate culture of green initiatives.

The purpose of a brand created by any firm is to develop a capability of long-term endurance (Srivastava et al., 2001). In order to develop this capability, firms are required to assume responsibility for action taken by their managers under the lens that reflects on building financial strength while respecting humanity and nurturing nature (Laczniak \& Santos, 2011). This requirement of sustainability encourages managers to create and capture opportunities that allow them to achieve the objectives that can be related to the triple bottom line theory, i.e., making profit for stakeholders, considering the well-being of people connected to the business and caring for the planet by conserving or making optimum use of natural resources for performing business (Jamali, 2008). Brand as a marketing tool takes centre stage and influences the various business opportunities encountered by different organisational functions towards triple bottom line objectives of the firm for superior 
performance. However, a difference in the brand's influence on the various opportunities available to three given organisational functions, i.e., operations, management and marketing is not known. Therefore, it is assumed that:

P3d: The impact from a strong brand to improve the ability of the firm to utilise the opportunities it has as an outcome of the sustainability-based corporate culture of green initiatives is higher for the "marketing" function in comparison to "operations", followed by "management".

\section{Research and Managerial Implications}

This research has created a research agenda for sustainability and branding researchers in the business domain. Past research on sustainability has evaluated the role played by the approach of sustainability in driving green initiatives adopted by firm managers and the ability of opportunities created from the firm as a result of these initiatives to drive superior performance. However, marketing researchers have failed to identify the role played by a brand in making the causal effect of opportunities on business performance stronger. Future research on this topic should identify specific variables that operate within the constructs and empirically test the framework conceptualised developed from a synthesis of existing knowledge from different domains. For the purpose of generalisation, the current research topic as reflected by the propositions made is very broad and we recommend that future researchers should further refine the topic using qualitative data before initiating a quantitative research.

The sustainability-based green initiatives of an industrial brand sold through retailers can create numerous opportunities for the organisation. Retailers enable the brand to trace every product sold to its consumers. The recycling of products becomes easier for a firm when they are either returned to retailers by customers or offered to customers by retailers with a brand name. Product sales information when available to marketing managers 
facilitates the success of brand loyalty programmes by encouraging existing users to return old products and buy new products. The used products returned by consumers to retailers create opportunities for refurbishment by the operations team, which makes used products ready to be sold to another set of customers who are keen to buy branded second-hand products at a low cost.

Firms that sell their products through retailer networks use brands to communicate their messages to consumers and develop brand associations for developing loyal customers (Peppard \& Rylander, 2006). Consumers gain confidence in the products or services offered by the brands based on what they understand as the value that the brand contributes to their lives (Fournier, 1998). Despite this, recent research on 'green' washing argues that there is no effect or influence of symbolic actions such as green washing on the performance of a firm from a financial perspective (Walker \& Wan, in press). Research on competitive markets highlights the relationship between understanding of the brand by the retailer and the important role that such an understanding plays in driving purchase decisions made by consumers (Gupta et al., 2010). While the objective of retailers is to earn profits from the sale of branded products and so they do not pay attention to the emotional aspects of brand communications (Webster, 1992; Gupta et al., 2010), consumers use brand communications to understand the strength of a brand to differentiate it from competing brands (Kent \& Allen, 1994). Because of the rational orientation of retailers' business interests, it becomes a challenge for managers to encourage retailers to participate in the green initiatives of the firm (Maignan \& McAlister, 2003).

However, brands can use their strong associations with consumers to recycle products at various stages of their life cycle (Kent \& Allen, 1994). Recycling products at different stages in the consumer segment requires a strong brand with which not only consumers but also retailers have a desire to be associated. Recycling of products reflects on the substantive 
value contributed by the firm for retailers and the symbolic value for the consumers and creates many marketing opportunities to identify customers who are ready to buy recycled, low cost products (Walker \& Wan, in press). When recycled products are supported by a strong brand name, their selling becomes easier for the retailer as the level of consumer confidence in the recycled products is high. Easy selling attracts retailers as it creates a faster exit of recycled products from their warehouse with faster generation of revenue.

\section{Acknowledgement}

We thank Renu for copyediting the manuscript 


\section{References}

Achrol, R. S. \& Kotler, P. (1999). Marketing in the network economy. Journal of Marketing, 63(1): 146-163.

Amit, R. \& Schoemaker, P. J. H. (1993). Strategic assets and organisational rent. Strategic Management Journal, 14(1): 33.

Amit, R. \& Zott, C. (2001). Value creation in e-business. Strategic Management Journal, 22(6/7): 493-520.

Baharum, M. R. \& Pitt, M. (2009). Determining a conceptual framework for green FM intellectual capital. Journal of Facilities Management, 7(4): 267-282.

Bansal, P. \& Roth, K. (2000). Why companies go green: A model of ecological responsiveness. Academy of Management Journal, 43(4): 717-737.

Batie, S. S. (1989). Sustainable development: Challenges to the profession of agricultural economics. American Journal of Agricultural Economics, 71(5): 1083-1101.

Beamon, B. M. (1999). Measuring supply chain performance. International Journal of Operations and Production Management, 19(3): 275-292.

Berger, P. D., Bolton, R. N., Bowman, D., Biggs, E., Kumar, V., Parasuraman, A. \& Terry, C. (2002). Marketing actions and the value of customer assets. Journal of Service Research, 5(1): 39-54.

Bernaur, T. \& Caduff, L. (2004). In whose interest? Pressure group politics, economic competition and environmental regulation. Journal of Public Policy, 24: 99-126.

Bose, R. \& Luo, X. (2011). Integrative framework for assessing firms' potential to undertake green IT initiatives via virtualization - a theoretical perspective. The Journal of Strategic Information Systems, 20(1): 38-54.

Boulatoff, C. \& Boyer, C. M. (2009). Green recovery: How are environmental stocks doing? Journal of Wealth Management, 12(2): 9-20.

Brammer, S. \& Walker, H. (2011). Sustainable procurement in the public sector: An international comparative study. International Journal of Operations and Production Management, 31(4): 452-476.

Breja, S. K., Banwet, D. K. \& Iyer, K. C. (2011). Developing a creative - inventive framework for strategic management and sustainable business excellence. International Journal of Productivity and Quality Management, 8(1): 1-32.

Bridges, C. M. \& Wilhelm, W. B. (2008). Going beyond green: The 'why and how' of integrating sustainability into the marketing curriculum. Journal of Marketing Education, 30(1): 33-46. 
Bronn, P. S. \& Vironi, A. B. (2001). Corporate social responsibility and cause-related marketing: An overview. International Journal of Advertising, 20(2): 207-222.

Campbell, A. J. (1998). Cooperation in international value chains: comparing an exporter's supplier versus customer relationships. Journal of Business and Industrial Marketing, 13(1): 22-39.

Cavalho, H., Azevedo, S. G. \& Cruz-Machado, V. (2010). Supply chain performance: Lean and green paradigms. International Journal of Business Performance and Supply Chain Modelling, 2(3-4): 304-333.

Chabowski, B. R., Mena, J. A. \& Gonzalez-Padron, T. L. (2011). The structure of sustainability research in marketing, 1958-2008: A basis for future research opportunities. Journal of the Academy of Marketing Science, 39: 55-70.

Charter, M. \& Clark, T. (2008). Product sustainability: Organisational considerations. International Journal of Product Development, 6(3-4): 251-275.

Chatterjee, P. (2009). Green brand extension strategy and online communities. Journal of Systems and Information Technology, 11(4): 367-384.

Chen, Y. (2010). The drivers of green brand equity: Green brand image, green satisfaction and green trust. Journal of Business Ethics, 93(2): 307-319.

Chernatony, L. \& Drury, S. C. (2006). Internal brand factors driving successful financial services bands. European Journal of Marketing, 40(5/6): 611-613.

Closs, D. J., Speier, C. \& Meacham, N. (2011) Sustainability to support end-to-end value chains: The role of supply chain management. Journal of the Academy of Marketing Science, 39: 101-116.

Coakes, E. W., Coakes, J. M. \& Rosenberg, D. (2008). Co-operative work practices and knowledge sharing issues: A comparison of viewpoints. International Journal of Information Management, 28(1): 12-25.

Crittenden, V. L., Crittenden, W. F., Ferrell, L. K., Ferrell, O. C. \& Pinney, C. C. (2011). Market-oriented sustainability: A conceptual framework and propositions. Journal of the Academy of Marketing Science, 39: 71-85.

Cronin J.J., Smith J.S., Gleim M.R., Ramirez E. and Martinez J.D. (2011), Green marketing strategies: An examination of stakeholder and the opportunities they present, Journal of the Academy of Marketing Science, 39: 158-174.

Dale, G. (2008) Green shift: An analysis of corporate responses to climate change. International Journal of Management Concepts and Philosophy, 3(2): 134-155.

Dangelico, R. M. \& Pujari, D. (2010). Mainstreaming green product innovation: Why and how companies integrate environmental sustainability. Journal of Business Ethics, 95(3): 471-486. 
Dao, V., Langella, I. \& Carbo, J. (2011). From green to sustainability: Information technology and integrated sustainability framework. The Journal of Strategic Information Systems, 20(1): 63-79.

Day, G. S. (2011). Closing the marketing capabilities gap. Journal of Marketing, 75(4): 183195.

Drongelen, I. K., Nixon, B. \& Pearson, A. (2000). Performance measurement in industrial R\&D. International Journal of Management Reviews, 2(2): 111-143.

Drumwright, M. E. (1994). Socially responsible organisational buying: Environmental concern as a non-economic buying criterion. Journal of Marketing, 58(3): 1-19.

Duncan, T. \& Moriarty, S. E. (1998). A communication based marketing model for managing relationships. Journal of Marketing, 62(2): 1-13.

Egan, C. \& Guilding, C. (1994). Dimensions of brand performance: Challenges for marketing and managerial accountancy. Journal of Marketing Management, 10(6): 449.

Elkington, J. (1998). Cannibals with forks: The triple bottom line of 21st century business. Stony Creek: New Society Publishers.

Ellen, P. S., Mohr, L. A., \& Webb, D. J. (2000). Charitable programs and the retailer: Do they mix? Journal of Retailing, 76(3): 393-406.

Eltayeb, T. K., Zailani, S. \& Filho, W. L. (2010). Green business among certified companies in Malaysia towards environmental sustainability: Benchmarking on the drivers, initiatives and outcomes. International Journal of Environmental Technology and Management, 12(1): 95-125.

Fadeeva, Z. (2005). Translation of sustainability ideas in tourism networks: Some roles of cross-sectoral networks in change towards sustainable development. Journal of Cleaner Production, 13(2): 175-189.

Fiol, C. M. (1991). Managing culture as competitive resource: An identity-based view of sustainable competitive advantage. Journal of Management, 17(1): 191-211.

Fournier, S. (1998). Consumers and their brands: Developing relationship theory in consumer research. Journal of Consumer Research, 24(4): 343-373.

Frame, B. \& Newton, B. (2007). Promoting sustainability through social marketing: Examples from New Zealand. International Journal of Consumer Studies, 31(6): 571581.

Funk, K. (2003). Sustainability and performance. MIT Sloan Management Review, 44(2): 6570.

Fuchs, D. A. \& Lorek, S. (2005). Sustainable consumption governance: A history of promises and failures. Journal of Consumer Policy, 28: 261-288. 
Fuller, T. \& Tian, Y. (2006). Social and symbolic capital and responsible entrepreneurship: An empirical investigation of SME narratives. Journal of Business Ethics, 67(3): 287304.

Galbrith, J. R., Kates, A. \& Downey, D. (2002). Designing dynamic organisations. AMACOM Division American Management Associations. AMCOM.

Garriga, E. \& Mele, D. (2004). Corporate social responsibility theories mapping the territory. Journal of Business Ethics, 53(1/2): 51-71.

Geng, Y. \& Yi, J. (2006). Integrated water resource management at the industrial park level: A case of Tianjin economic development area. International Journal of Sustainable Development and World Ecology, 13(1): 37-50.

Grace, D. \& O'Cass, A. (2002). Brand associations: Looking through the eye of the beholder. Qualitative Market Research: An International Journal, 5(2): 96-111.

Gunasekaran, A., Goyal, S. K., Martikainen, T. \& Yi-Olli, P. (1998). Total quality management: A new perspective for improving quality and productivity. International Journal of Quality and Reliability, 15(8/9): 947-968.

Gupta, A. D. (2007). Social responsibility in India towards global compact approach. International Journal of Social Economics, 34(9): 637-663.

Gupta, S., Melewar, T. C. \& Bourlakis, M. (2010). A relational insight of brand personification in business-to-business markets. Journal of General Management, 35(4): 65-76.

Halme, M. \& Laurilla, J. (2009). Philanthropy, integration or innovation? Exploring the financial and societal outcomes of different types of corporate responsibility. Journal of Business Ethics, 84(3): 325-339.

Hart, S. L. (1995). A natural resource-based view of the firm. Academy of Management Review, 20: 986-1014.

Hart, S. L. (1997). Beyond greening: strategies for a sustainable world. Harvard Business Review, 75(1), 66-76.

Jamali, D. (2008). A stakeholder approach to corporate social responsibility: A fresh perspective into theory and practice. Journal of Business Ethics, 82(1): 213-231.

Jap, S. D. (2001). Perspectives on joint competitive advantages in buyer-supplier relationships. International Journal of Research in Marketing, 18(1-2): 19-35.

Judge, W. Q. \& Douglas, T. J. (1998). Performance implications of incorporating natural environmental issues into the strategic planning process: An empirical assessment. Journal of Management Studies, 35(2): 241-262.

Kantabutra, S. \& Avery, G. C. (2011). Sustainable leadership at Siam Cement Group. Journal of Business Strategy, 32(4): 32 - 41. 
Kemp, P., Patro, S. \& Gibson, R. B. (2005). Governance for sustainable development: Moving from theory to practice. International Journal of Sustainable Development, 8(1/2): 12-30.

Kent, R. J., \& Allen, C. T. (1994). Competitive inference effects in consumer memory for advertising: The role of brand familiarity. Journal of Marketing, 58 (3): 97-105.

Kohli, A. K. \& Jaworski, B. J. (1990). Market orientation: The construct, research propositions and managerial implications. Journal of Marketing, 54(2): 1-18.

Laczniak, G. R. \& Santos, N. J. C. (2011) The integrative justice model for marketing to the poor: An extension of S-D logic to distributive justice and macromarketing. Journal of Macromarketing, 31(2): 135-147.

LeBreton, W., Casavant, T. \& Cote, R. (2004). Small scale eco-industrial networking: Interorganisational collaborations to yield system wide benefits in communities. Progress in Industrial Ecology, an International Journal, 1(4): 432-453.

Lee, C., Lee, K. \& Pennings, J. M. (2001). Internal capabilities, external networks and performance: A study on technology-based ventures. Strategic Management Journal, 22(6-7): 615-640.

Liu, A. \& Liu, H. J. (2009). Government approaches to tourism: An international inquiry. International Journal of Tourism Policy, 2(3): 221-238.

Lockwood, C. (2006). Building the green way. Harvard Business Review, 84(6): 129-137.

Maignan, I. \& McAlister, D. T. (2003). Socially responsible organisational buying: How can stakeholders dictate purchasing policies. Journal of Macromarketing, 23(2): 78-89.

Marrewijk, M. v. (2003). Concepts and definitions of CSR and corporate sustainability: Between agency and communion. Journal of Business Ethics, 44(2/3): 95-105.

McKinnon, A. C. (2010). Product-level carbon auditing of supply chains: Environmental imperative or wasteful distraction? International Journal of Physical Distribution and Logistics Management, 40(1/2): 42-60.

Melynk, S. A., Sroufe, R. P. \& Calantone, R. (2003). Assessing the impact of environmental management systems on corporate and environmental performance. Journal of Operations Management, 21(3): 329-351.

Menon, A. \& Menon, A. (1997). Enviropreneurial marketing strategy: The emergence of corporate environmentalism as market strategy. Journal of Marketing, 61(1): 51-67.

Mentzer, J. T., Min, S. \& Zacharia, Z. G. (2000). The nature of interim partnering in supply chain management. Journal of Retailing, 76(4): 549-568.

Miller, D. (2003). An asymmetry-based view of advantage: Towards an attainable sustainability. Strategic Management Journal, 24(10): 961-976. 
Minoli, D. (2010). Designing green networks with reduced carbon footprints. Journal of Telecommunication Management, 3(1): 15-35.

Mont, O. K. (2002). Clarifying the concept of product-service system. Journal of Cleaner Production, 10(3): 237-245.

Munasinghe, M. (2001). Sustainable development and climate change: Applying the sustainomics transdisciplinary meta-framework. International Journal of Global Environmental Issues, 1(1): 13-55.

Newton, T. \& Harte, G. (1997). Green business: Technicist Kitsch? Journal of Management Studies, 34(1): 75-98.

Olson, P. D., Zuiker, V. S., Danes, S. M., Stafford, K., Heck, R. K. Z. \& Duncan, K. A. (2003). The impact of the family and business on family business sustainability", Journal of Business Venturing, 18(5): 639-666.

Osland, J. S. (2003). Broadening the debate: The pros and cons of globalization. Journal of Management Enquiry, 12(2): 137-154.

Ostorm, A. L., Bitner, M. J., Brown, S. W., Bukhard, K. A., Goul, M., Smith-Daniel, V., Demirkan, H. \& Robinovich, E. (2010). Moving forward and making a difference: Research priorities for the science of service. Journal of Service Research, 13(1): 4-36.

Palmatier, R. W., Scheer, L. K., Houston, M. B., Evans, K. R. \& Gopalakrishna, S. (2007). Use of relationship marketing programmes in building customer-salesperson and customer-firm relationships: Differential influences on financial outcomes, International Journal of Research in Marketing, 24: 210-223.

Payne, A., Storbacka, K., Frow, P. \& Knox, S. (2009). Co-creating brands: Diagnosing and designing the relationship experience. Journal of Business Research, 62(3): 379-389.

Peloza, J. \& Shang, J. (2011). How can corporate social responsibility activities create value for stakeholders? A systematic review. Journal of the Academy of Marketing Science, 39: 117-135.

Peppard, J. \& Rylander, A. (2006). From value chain to value networks: Insights from mobile operators, European Management Journal, 24(2-3): 128-141.

Perrini, F. (2006). SMEs and CSR theory: Evidence and implications from an Italian perspective. Journal of Business Ethics, 67(3): 305-316.

Piercy, No.(2009). Positive management of marketing-operations relationships: The case of an internet retail SME. Journal of Marketing Management, 25(5-6): 551-570.

Pomering, A. \& Dolnicar, S. (2009). Assessing the prerequisite of successful CSR implementation: Are consumers aware of CSR initiatives? Journal of Business Ethics, 85(2): 285-301. 
Pujari, D., Wright, G. \& Peattie, K. (2003). Green and competitive: Influences on environmental new product development performance. Journal of Business Research, 56(8): 657-671.

Ramani, G. \& Kumar, V. (2008). Interaction orientation and firm performance. Journal of Marketing, 72: 27-45.

Ratnayake, R. M. C. \& Liyanage, J. P. (2009). Asset integrity management: Sustainability in action, International Journal of Sustainable Strategic Management, 1(2): 175-203.

Razzaque, M. A. (1998). Scientific method, marketing theory development and academics vs practitioner orientation: A review. Journal of Marketing Theory and Practice, 6(1): 1-15.

Roberts, J. \& Merrilees, B. (2007). Multiple role of brands in business-to-business services. Journal of Business and Industrial Marketing, 22(6): 410-417.

Rodrigues, S. \& Child, J. (2008). The development of corporate identity: A political perspective. Journal of Management Studies, 45(5): 885-911.

Rogers, D. S., Lambert, D. M., Croxton, K. L. \& Gracia-Dastugue, S. J. (2002). The returns management process. International Journal of Logistics Management, 13(2): 1-18.

Rondinelli, D. A. \& Berry, M. A. (2000). Environmental citizenship in multinational corporations: Social responsibility and sustainable development. European Management Journal, 18(1): 70-84.

Russo, M. V. \& Fouts, P. A. (1997). A resource-based perspective on corporate environmental performance and profitability. The Academy of Management Journal, 40(3): 534-559.

Rust, R. T., Ambler, T., Carpenter, G. S., Kumar, V., Srivastava, R. K. (2004). Measuring marketing productivity: Current knowledge and future directions. Journal of Marketing, 68(4): 76-89.

Sarkis, J., Meade, L. M. \& Talluri, S. (2004). E-logistics and natural environment. Supply Chain Management: An International Journal, 9(4): 303-312.

Seuring, S. \& Muller, M. (2008). From a literature review to a conceptual framework for sustainable supply chain management. Journal of Cleaner Production, 16(15): 16991710 .

Sheth, J. N., Sethia, N. K. \& Srinivas, S. (2011). Mindful consumption: A customer-centric approach to sustainability. Journal of the Academy of Marketing Science, 39: 21-39.

Shrivastava, P. (1995). Environmental technologies and competitive advantage. Strategic Management Journal, 16: 183.

Smith, A. D. (2010). Growth of corporate social responsibility as a sustainable business strategy in difficult financial times. International Journal of Sustainable Economy, 2(1): 59-79. 
Snoj, B., Korda, A. P. \& Mumel, D. (2004). The relationships among perceived quality, perceived risk and perceived product value. Journal of Product \& Brand Management, 13(3): 156-167.

Srivastava, R. K., Shervani, T. A. \& Fahey, L. (1998). Market-based assets and shareholder value: A framework for analysis. Journal of Marketing, 62(1): 2-18.

Srivastava, R. K., Fahey, L. \& Christensen, H. K. (2001). The resource-based view and marketing: The role of market-based assets in gaining competitive advantage. Journal of Management, 27(6): 777-802.

Stone, L. J. (2006). Limitations of cleaner production programmes as organisational change agents. II. Leadership, support, communication, involvement and programme design. Journal of Cleaner Production, 14(1): 15-30.

Stubbs, M. (2004). Heritage-sustainability: developing a methodology for the sustainable appraisal of the historic environment. Planning, Practice and Research, 19(3): 285-305.

Sundarakani, B., DeSouza, R., Goh, M., Wagner, S. M. \& Manikandan, S. (2010). Modeling carbon footprints across the supply chain. International Journal of Production Economics, 128(1): 43-50.

Swaney, J. A. (1987). Elements of a neo-institutional environmental economics. Journal of Economic Issues, 21(4): 1739-1779.

Szekely, F. \& Knirsch, M. (2005). Responsible leadership and corporate social responsibility: Metrics for sustainable performance. European Management Journal, 23(6): 628-747.

Teece, D. \& Pisano, G. (1994). The dynamic capabilities of firms: An introduction. Industrial and Corporate Change, 3(3): 537-556.

Urde, M. (1999). Brand orientation: a mindset for building brands into strategic resources. Journal of Marketing Management, 15(1-3): 117-133.

Waddock, S. (2004). Creating corporate accountability: Foundational principles to make corporate citizenship real. Journal of Business Ethics, 50(4): 313-327.

Walker, K. \& Wan, F. (in press). The harm of symbolic actions and green-washing: Corporate actions and communications on environmental performance and their financial implications. Journal of Business Ethics, DOI 10.1007/s10551-011-1122-4

Webster, F. E. (1992). The changing role of marketing in the corporation. Journal of Marketing, 56(4): 1.

Weerawardena, J., O'Cass, A. \& Julian, C. (2006). Does industry matter? Examining the role of industry structure and organisational learning in innovation and brand performance. Journal of Business Research, 59(1): 37-45. 
Wehling, C., Hernandez, A. G., Osland, J., Osland, A., Deller, J., Tanure, B., Neto, A. \& Sairaj, A. (2009). An exploratory study of the role of HRM and the transfer of German MNC sustainability values to Brazil. European Journal of International Management, 3(2): 176-198.

Wheeler, D., Colbert, B. \& Freeman, R. E. (2003). Focusing on value: Reconciling corporate social responsibility, sustainability and a stakeholder approach in a network world. Journal of General Management, 28(3): 1-28.

White, C. D., Masanet, E., Rosen, C. M. \& Beckman, S. L. (2003). Product recovery with some byte: An overview of management challenges and environmental consequences in reverse manufacturing for the computer industry. Journal of Cleaner Production, 11(4): 445-458.

Williamson, D., Lynch-wood, G. \& Ramsay, J. (2006). Drivers of environmental behaviour in manufacturing SMEs and the implications for CSR. Journal of Business Ethics, 67(3): 317-330.

Wong, V., Turner, W. \& Stoneman, P. (1996). Marketing strategies and market prospects for environmentally-friendly consumer products. British Journal of Management, 7(3): 263281. 
Figure 1: Linking Sustainability, Functions \& Performance

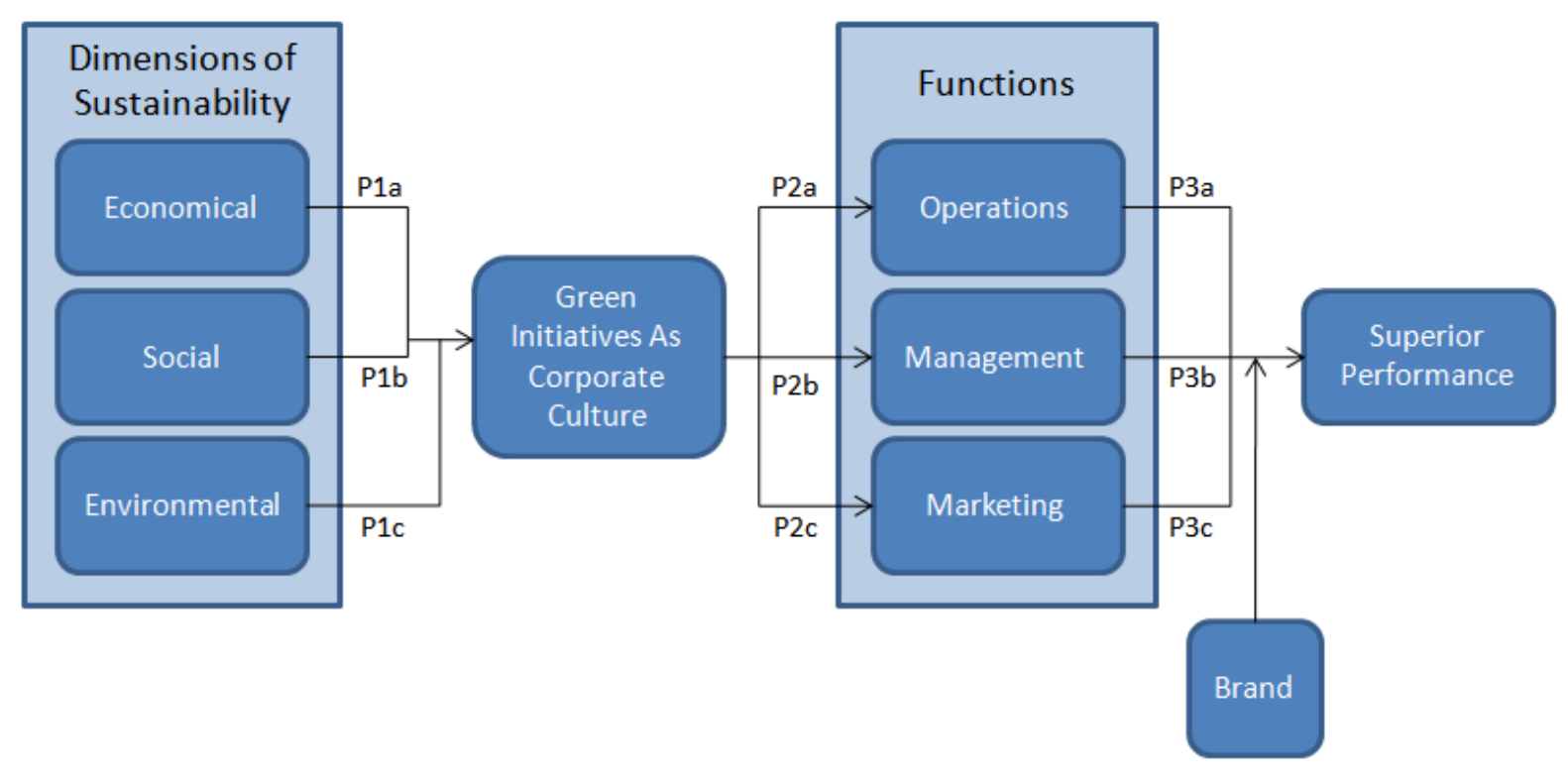


Table 1: Practical Implications For Different Dimensions Of Sustainability

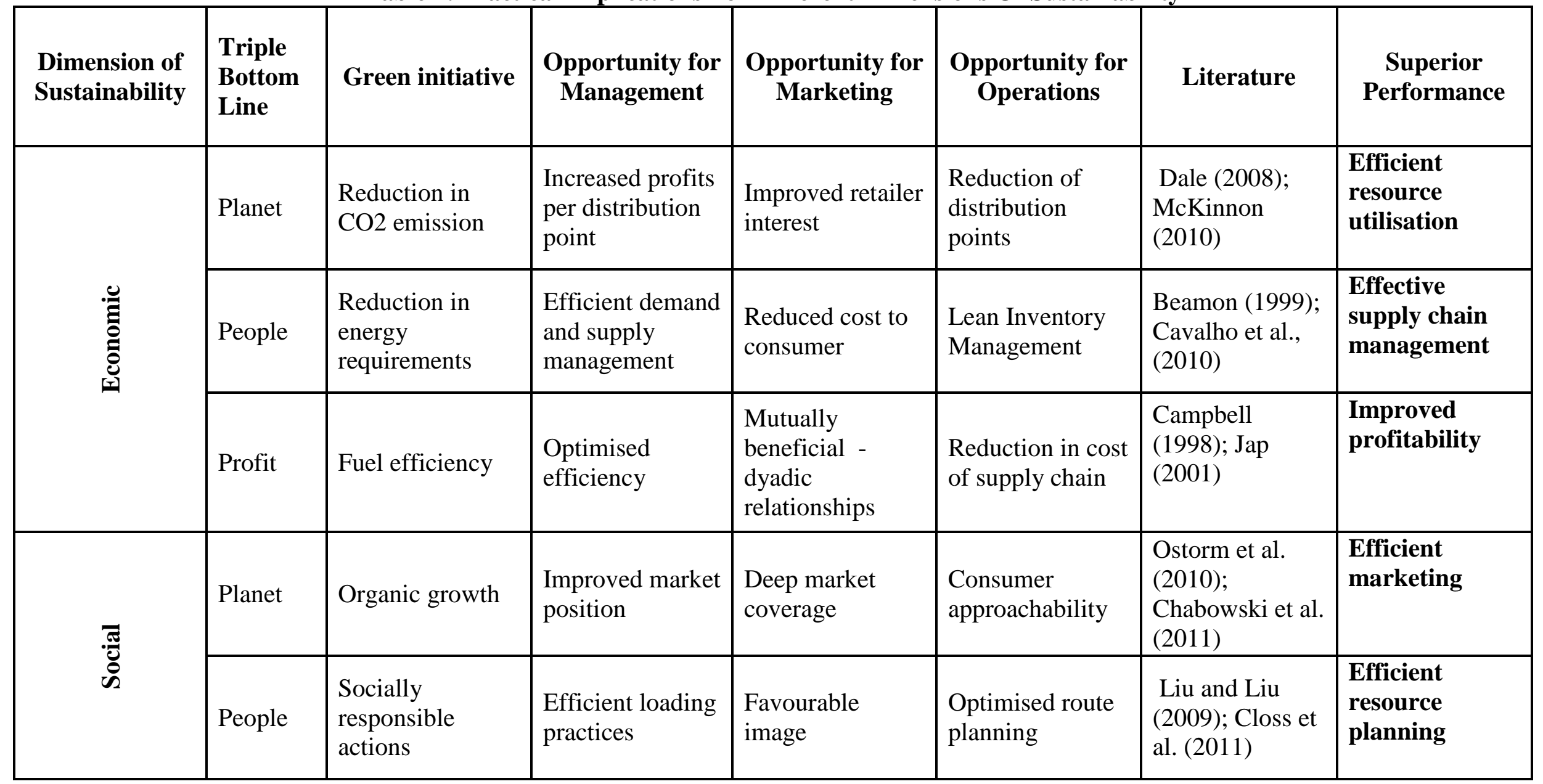




\begin{tabular}{|c|c|c|c|c|c|c|c|}
\hline & Profit & $\begin{array}{l}\text { Efficient product } \\
\text { recycling }\end{array}$ & $\begin{array}{l}\text { Strategic } \\
\text { planning }\end{array}$ & $\begin{array}{l}\text { Promote } \\
\text { products at } \\
\text { different stages } \\
\text { of life cycle }\end{array}$ & $\begin{array}{l}\text { Network } \\
\text { Optimisation }\end{array}$ & $\begin{array}{l}\text { Mont (2002); } \\
\text { White et al. } \\
\text { (2003) }\end{array}$ & $\begin{array}{l}\text { Efficient } \\
\text { product } \\
\text { management }\end{array}$ \\
\hline 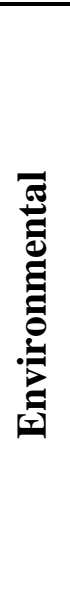 & Profit & $\begin{array}{l}\text { Integration of } \\
\text { upstream and } \\
\text { downstream } \\
\text { movements }\end{array}$ & $\begin{array}{l}\text { Improved } \\
\text { dispersal }\end{array}$ & $\begin{array}{l}\text { Improved } \\
\text { customer } \\
\text { knowledge }\end{array}$ & $\begin{array}{l}\text { Assessment of } \\
\text { consumption }\end{array}$ & $\begin{array}{l}\text { Sundarakani et } \\
\text { al. (2011); Sheth } \\
\text { et al. (2011) }\end{array}$ & $\begin{array}{l}\text { Improved } \\
\text { market } \\
\text { assessment }\end{array}$ \\
\hline
\end{tabular}

